\title{
Contemporary Polish surnames motivated BY APPELLATIVES RELATED TO RELIGION
}

\author{
JUSTYNA B. WALKOWIAK \\ Adam Mickiewicz University in Poznań, Poland
}

\begin{abstract}
Certain surnames currently used in Poland are motivated by religious terms: adjectives referring to Christian morality (Grzeszny 'sinful', Miłosierny 'merciful'), the Bible (Apostot 'apostle', Herod, Piekielny 'of hell'), pious exclamations (Bożemój 'my God!', Laboga 'by God!'), Latin or Polish prayers (Oremus 'let us pray', Ojczenasz 'Our Father'), and terms for vestments or other church objects (Rokieta 'rochet', Kropidto 'aspergillum'). There is also a group related to non-Catholic denominations and their rituals: Luter 'protestant', Pogan 'pagan', Panachida 'memorial service in the Eastern Orthodox Church', Kadysz 'Kaddish'. These surnames are discussed with respect to their frequency and possible motivation.
\end{abstract}

Keywords: surnames, religion, church, Christianity, Latin.

\section{Introduction}

The advent of Christianity in Poland, formally effected in 966, meant a profound cultural change which, among other spheres of social life, also had a major influence on anthroponomastics. This influence was exercised in two distinct ways. The more obvious one was the gradual replacement of the bulk of pagan personal names with Judeo-Christian onymy. The process markedly accelerated in the $16^{\text {th }}$ century after the Council of Trent, though never ultimately completed (i.e. some pre-Christian names survived, and some in the $19^{\text {th }}$ century underwent a revival).

Less directly visible, although no less important, was the introduction of Christian culture and imagery into nicknames, later to become fixed surnames. The latter will be the subject of the present article. Over 400 surnames motivated by appellatives related to religion are discussed below. They can be divided according to mixed, semantic-syntactic classifying criteria: semantic - according to the type of motivation, and syntactic - according to formal properties of the word or phrase motivating the anthroponym.

\section{Adjectives applicable to people (e.g. pious, sinful, innocent) and their nominal derivatives}

The first group of interest for us here will be surnames motivated by adjectives referring to a person's character and behaviour viewed in the light of the Christian doctrine. They include the following names: Boski $198^{1}$ (from boski 'divine'), Nabożny 639,

\footnotetext{
1 The number after each surname refers to the number of its bearers according to Rymut
} 
Pobożny 32, Pobożniak 163, Poboży/Poboża 228, Zbożny 28, Zbożniak 33, Zbożnik 34 (from nabożny, pobożny, zbożny, all meaning 'pious'), Zbawiony 72 (zbawiony 'saved'), Święty 609/Świenty 169 (< święty 'saint, sacred'), Świętoszek 6 (świętoszek 'prude' < święty), Winny 181 (winny 'guilty', wina 'guilt', but also winny 'of wine/vine; sweet and sour in taste', cf. wino 'wine'), Niewinny 97 (niewinny 'innocent'), Śmiertelny 18 (śmiertelny 'mortal'), Nieśmiertelny 26 (nieśmiertelny 'immortal'), Mitosierny 'merciful', Nieczysty 12 (nieczysty 'impure'), Grzeszny 94 (grzeszny 'sinful' < grzech 'sin'), Grzesznik 94 (grzesznik 'sinner') and Zynder 36, Sinder 13, Synder 9 (from German Sünder 'sinner', cf. Breza 2004a: 133; perhaps the following names are its derivatives: Synderczyk 8, Synderecki 26, Synderek 4, Synderkiewicz 17, Synderowski 23, Synderski 4); Pomaz 4, Pomazan 6, Pomazany 38, Pomazański 41, Pomazanka 69 (all from pomazany/pomazaniec 'Messiah, God's anointed one', cf. the personal name Pomazek, attested in 1499).

\section{Nouns relating to the afterlife}

A separate semantic field comprises the afterlife in the Christian doctrine. Thus, the Polish appellative piekto 'hell' gave rise to the following surnames: Piekto 701, Piekietko 289, Piekiełek 143, Piekielniak 392, Piekielnicki36, Piekielnik 178, Piekielski 111, Pieklak 164, Pieklik 310, Pieklus 11, Piektowski 48, Piekielny 458 (cf. piekielny 'hellish'). The appellatives raj and niebo 'paradise' became the motivation for Raj 1633, Rajski 2608 (cf. rajski 'of Paradise') and Niebo 12. This number might be extended by several more surnames reminiscent of Latin paradisus 'paradise': Paradysz 391, Paradisz 10, Paradzisz 2, Paradies 18 (German spelling), Paradyz 29. This motivation also finds reflection in other Slavic languages, a case in point being the Russian or Bulgarian surname Парадизов. Only one surname - Czyściecki 50 - is traceable to czyściec 'purgatory'.

It must be borne in mind, though, that in contemporary Poland there are at least four villages or settlements (and a cave) by the name Raj, three villages called Paradyż, two villages - Czyściec, as well as over a dozen villages or their parts named Piekło. Therefore, many of the above-mentioned surnames might be toponymic.

\section{Names of various denominations}

Somehow surprisingly, perhaps, the surname Katolik, first attested in 1690, is not so rare (487) as one might expect of a society that traditionally used to equate being a Pole with adherence to Catholicism - assuming, naturally, that a name is to distinguish a person from the crowd (to put it differently, a surname from a nickname meaning 'farmer' is not highly likely to emerge in a community whose members are predominantly farmers). The name Katolicki 30 is its likely derivative. The impact of Reformation is visible in the names Luter 336, Luterek 576, Luteracki 19, Lutarek 1, Lutarewicz 70. However, in some cases the origin of the surname must have been the German name Luther, since the same-sounding personal name (proto-surname?) was first attested in 1359, whereas the Reformation started only in 1517. 
There is also a series of family names derived from the name of the spiritual leader Jean Calvin: Kalwinek 117, Kalwiński 51, Kalwinicki 6, Kalwiniak 1. Some of them perhaps do not so much indicate the faith as such, but rather reflect the appellative kalwin - once meaning 'godless person, non-believer, doubter' (cf. Rymut 1999: 369). A similar sense is carried by the surname Heretyk 182 (from the appellative heretyk 'heretic', cf. Breza 2004a: 137, though it might also be a distorted version of the given name Harat $<$ Artym). The appellatives kacerz and kociarz (kocia wiara being a colloquial expression for a religion different from the Catholic one, especially referring to one of the Protestant groups) may have occasioned the names Kacerz 10, Kociarz 44, Kociara 90, Kociarski 4 (or in some cases perhaps just from the appellative kot 'cat') ${ }^{2}$. The name Babtyst 10 obviously refers to the protestant group(s) known as Baptists (Polish baptyści, singular baptysta), and Starowierow 2 - to Old Believers (Polish starowierzy, starowiercy, staroobrzędowcy, cf. stary 'old', wiara 'faith'). Several names owe their existence to the appellatives uniat/unita 'member of the Ruthenian Uniate Church', cf. unia 'union': Uniat 23, Uniatowicz 25, Uniatowski 125, Uniatycki 4, Unicki 34, Unijat 5, Unijewski 53 (cf. Breza 2004b: 150-151).

Only a few surnames can be traced to the names of members of non-Christian denominations and akin words. Among these, there are a handful surnames inspired by kabata 'Kabbalah': Kabata 2036 (first attested in 1398), Kabatyk 12, Kabala 820, Kabalak 97, Kabalec 50, Kabalewicz 1, Kabalewski 2, Kabalski 34. The related personal name Kabatka, today extinct, was first attested in 1401. As Rymut (1999: 362) points out, the appellative kabała may have figuratively meant 'problem, trouble' as well. The Karaite community, once within the confines of the Polish-Lithuanian Commonwealth (in Trakai, near Vilnius), is directly evoked in the names Karaim 68, Karaimow 12 (cf. Polish appellative karaim, karaita), while the reference to Muslims (Polish sara-

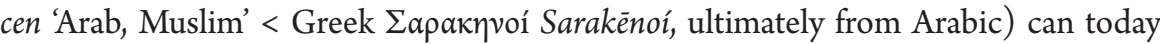
be detected in the surnames Saracen 239, Saraceń 7, Saracin 3, Saracyn 179, Saracyń 3, Saraczyn 57, Saraczyński 6, Seraczyn 9. Pagans are evoked in the surnames Pogan 368, Poganiec 18, Pogański 2, Pagan 2, Poganis 4 (< Lithuanian paganis 'pagan'); poganin once meant not only a pagan, but generally 'non-Christian, idolater, infidel, heathen, godless person' (cf. SWil 1090).

\section{The Bible}

Quite many surnames have been motivated by the Scriptures. However, in what follows Biblical names have been consciously disregarded because of their sheer number. Only those Biblical personages that in the Polish culture have not occasioned Christian (given) names (contemporary or historical) are included here. First and

2 The appellative kacerz is derived from Old Czech kacier $<$ German Ketzer $<$ Greek katharós 'pure' (SJPDor). However, the colloquial phrase kocia wiara may also be related to koci zamek - an anoikonym referring to the former existence in that place of a Hussite wagon fort (from distorted Hungarian kocsi 'wagon, coach, cart') - cf. Kryciński (2016: 125-127).

3 The old name for the Eastern Catholic Churches, in full communion with the Pope. 
foremost, the name Jesus (Polish Jezus) must be discussed. In the Polish culture it has always been considered inappropriate for mortals, which also explains the scarcity of patronymic surnames based on the given name Jezus. Nevertheless, certain surnames, probably derived from nicknames with the ironic meaning 'prude', contain the root Jez-/Jeż- traceable to this name: Jezusek 429, Jezutek 40, Jezuzek 1, Jezyszek 1, Jeżyszek 19. By contrast, in the Hispanic culture Jezus as a given name is common. Consequently, the surname Jezus is frequent in Portugal (\#9 in 20044). The Spanish equivalent is de Jesús ('of Jesus'), with spelling variants de Jesus, DeJesus, Dejesús.

The appellative patriarcha 'patriarch' gave rise to Patriarcha 4, Patrjach 10, Patryarcha 202, Patryjarcha 4, Patryjach 10, Patryjak 44, Patryarsz 8, Patrias 85, Patrijas 6, Patryas 152, Patryjas 65 5 . From prorok 'prophet' the following are derived: Prorok 1699, Prorocki 16, Prorokowski 6. The word apostot 'apostle' lies at the root of the contemporary surnames Apostol 148, Apostol 1, Apostolik 34, Apostolski 113, Apostoluk 105, Apostołow 5, Apostołowicz 47, Apostót 2, Postoł 114, Postolski 239, Postót 149 and German-based Apostel 616. While the forms with Pos- may have resulted from the apheresis of the initial vowel, an alternative etymology might be postot/postoly 'kind of simple shoe: the foot is bound with a piece of cloth, with a rectangular piece of leather with holes in the function of the sole' (SWil 1150, Rymut 2001: 283, Breza 2002: 348350 ). There is only one surname (Ewangelista 42) that relates directly to the authors of the Holy Writ and does not mention their names.

The good supernatural beings mentioned in the Bible include angels (cf. Polish aniot and the surnames Anioł 3827, Aniota 659, Aniotczyk 132, Aniotek 469, Aniotkiewicz 58, Aniotkowski 494, Aniotowicz 3, Aniołowski 209, Archaniołowicz 68; Latin angelus and the surnames Angel 249, Angelus 68, Angelis 4, Angielus 3 and Eastern Slavic Angietow 4, Angiel 202; cf. Breza 2004b: 140) and cherubs (cf. Polish appellative cherubin, earlier cherub < Akkadian karabu, and the surnames Cherubin 267, Cherubinski 39, Herubin 92, Herubinski 44). The derivatives of Serafin will not be discussed here since this used to be a Christian name in Poland.

Among the evil Biblical spirits there is, first and foremost, the devil. Its many Polish names - szatan, diabet, bies, czart, boruta - gave rise to many diverse surnames. Thus, szatan (< Hebrew satan, Greek $\sum a \tau \alpha v a \tilde{s}$, Satanás) can be traced in the names Szatan 2214, Szatanek 427, Szataniak 214, Szatanik 1060, Szatanowski 81, Szatański 272, Szataniuk 1, Szatańczyk 1, Satan 13, Satanowski 61, Satanik 2. The word diabet is recognisable in Diabelec 52, Diabetek 42, Diableń 5, Diabutek 7, Diawot 20 and Diawit 1 (Ukrainian - cf. Breza 2004b: 143). The names Bies 608, Biesak 24, Biesiakiewicz 4, Biesek 734, Biesik 246, Biesicki 32, Biess 2, Biessek 10, Bis 2168, Bisa 14, Bisacki 17, Bisak 62, Bisakowski 9, Bisecki 3 and probably some others all owe their existence to the appellative bies/bis. The surnames Korfanty 454 and Korfant 19 reflect the $17^{\text {th }}$-century

\footnotetext{
4 http://anossavida.pt/sites/default/files/100_apelidos.pdf, accessed 17.04.2017.

5 On the spelling variants cf. http://www.wtg-gniazdo.org/forum/viewtopic. $\mathrm{php} ? \mathrm{p}=84217$
} 
Silesian appellative korfanty 'devil' (Brückner 1927: 257). The archaic appellative tukawy 'evil spirit' (also 'sly, insidious; greedy; envious', cf. Arct 163) finds its reflection in Eukawy 77 (40 male bearers of this form, 31 women with the feminine name Eukawa, and 6 women bearing the masculine form). The appellative czart is detectable in Czart 223, Czartek 42 and Czartowski 159. A more dialectal, familiar version, Boruta, finds its reflection in Boruta 2758, Borutka 50, Borutko 27, Borutta 12. Considering that boruta is also the name of a pre-Christian (pagan) Slavic demon, the list of his alternative names could be extended to include e.g. borowy, borowiec, leszy, laskowiec, laskowy, leśnik, gajowy, leśny dziad and others. Most of these names have high-frequency equivalents among contemporary Polish surnames - if not for any other reason, then at least by virtue of the fact that the general meaning of each is roughly '(the inhabitant) of the wood/grove', which makes them etymologically indistinguishable from toponymic surnames ${ }^{6}$. Therefore, they will not be discussed in more detail here. Similar considerations preclude the inclusion of the surname Rokita, which may have originated not only from the name of a Slavic demon, but also from a plant name (Latin Salix rosmarinifolia 'rosemary-leaved willow').

Similarly motivated are the surnames Mannteufel 9, Manteufel 202, Manteuffel 25, Manteuffell 2 and - in Polonised orthography - Mantojfel 40. In its original orthography, Manteuffel, this is the surname of a well-known noble family from Pomerania. The High German noun Mannteufel, corresponding to the Low German Manduvel, denotes 'the devil's servant', thus being an antonym to Gottschalk 'God's servant'. An older Polish version of the name (attested at the end of the $13^{\text {th }}$ century, in 1640, recorded as Mandywet; cf. Kościński 1906: 118) is continued to this day in the form Mandywel 7. According to Breza (2000: 121), all these stem ultimately from Low German Düvel 'devil'/High German Teufel. As Breza (2000: 121) points out, there is also a nickname mandivel in Kashubian, as well as a Kashubian byname Mandywel. The above-mentioned Low German Düvel gave rise to the surnames Dywel 106 and Dywelski 105.

A Biblical place name of exceptional importance is certainly Jerusalem, the source of many surnames in Polish: Jeruzalem 55, Jeruzal 417, Jeruzalski 271, Jeruzel 78, Jerusel 16, Jeruzelski 2, Jeruzol 30, Jerużalski 30, Jaruzal 79, Jaruzalski 5, Jaruzel 224, Jaruzelski 19, Jerozalski 46, Jerożalski 3, Jerozolimski 18. Most of these are probably coinages from Polish toponyms: for instance, there are three villages in Poland by the name of Jeruzal. The name of one of them, in Skierniewice County, was recorded as Jeruszel in 1520 and as Jaruzel in 1579 (SGKP XV/2: 19). The Jaruzelski family is known to have been living there in the $16^{\text {th }}$ century, which makes it likely that the toponym preceded the surname. There is also a village in Poland called Jeruzale, and another one - Jeruzalem (in Kashubia).

Another Biblical name reflected in the Polish anthroponymy is Sodoma (Sodom) in the sense of 'place of depravity': Sodoma 73, Sodomlak 18, Sodomski 33, Sadomski

6 In Van Langendonck's categories, this would correspond to the difference between characterising and relational surnames (cf. Van Langendonck 2012: 225-226). 
69. An intriguing form is Sodomora 12 - maybe a portmanteau word coined from the pair Sodoma i Gomora ('Sodom and Gomorrah'). Pasja 'passion' (of Christ) gave rise to Pasja 84 and Pasjak 17. Judas Iscariot motivated the appellative judasz 'traitor', hence the surnames Judasz 440, Judas 47, Judasik 157; lewita 'Levite' (descendant of Levi in the male line) lies at the root of the surname Lewita 41. Finally, the name Dydymski 272 probably comes from Thomas the Apostle, called Didymus.

\section{Pious exclamations and other theophoric onyms}

An interesting group of surnames derives from exclamations and invocations to God. Van Langendonck (2012: 226) calls such names delocutives. They comprise those meaning 'by God! For God's sake!', that is, Dlaboga 6, Dlabocha 4, Laboga 28, Łoboga 1. Some mean 'my God': Bożemój 24, Borzemój 4. Several have the sense 'God give, may God give', some later meant 'indeed': Bożedaj 20, Bożedajek 59, Bożydaj 14, Dadzibóg 8 89, Dadzibug 16, Dajbóg 3, Dalibóg 2, Dolibóg 188, Dolibog 65, Dolibok 3. Yet others carry the meaning '(by) dear God': Miłobóg 50, Mitobog 2. Somewhat unclear are Modlibóg 7 (modlić się 'to pray'), Pobóg 73, Jaksiboga 7. Finally, the surnames Ponachajba 46, Ponagajbo 8 and Ponahajba 16 all go back to the Ukrainian panahajbo '[may] God help' (Rymut 2001: 277), cf. the Ukrainian name Панагайбо and Russian Панагайбо, Панагайба and Панагбеев.

Some other theophoric surnames include: Bogochwalski 5, Bogolubow 9, Bogomilski 3/Bogumilski 11 - from bogumily 'acceptable to God' ', Bogorodzki 8, Bogorodź 78, Bohorodycz 36, Bohorodzicz 9, Bochorodycz 14 (all from Bogurodzica 'Mother of God' or its Eastern Slavic variants), Bogójawleński 13, Bogudał 71 (see also Szczaus 2003).

However, the seemingly theophoric surname Bogowolski 11 (cf. Bóg 'God', wola 'will') is actually derived from boguwola, the folk name of the bird golden oriole (Latin Oriolus galbula or Oriolus oriolus).

\section{Snippets of church language in Latin}

As Breza (2000: 250-251) aptly emphasizes, nicknames echoing religious Latin phrases were once given to people connected with the church: perhaps, for example, they repeated awkwardly after the priest the words of Latin prayers. One has to remember that until the 1960s the language of the Catholic Church was Latin. Today several Latin phrases in surnames are still recognisable. Among them, there is Oremus 'let us pray' 110 , with secondary surnames Oremczak 7, Oremczuk 39, Oremek 145, Oramus 521, Oram 18 and Orymus 12; interestingly, there is also a colloquial appellative

\footnotetext{
7 However, direct transition from personal name cannot be ruled out (Judas was also the name of another apostle in the New Testament, otherwise known as Judas Thaddaeus).

8 In Slavic mythology Dadźbóg/Dabóg/Dażboh is an east Slavic god of the Sun, presumably also of wealth and fire, often identified with Swarożyc (cf. Poniatowski 1969: 84).

9 Cf. the Bible, Romans 12:1-2 (New King James version). Nevertheless, this surname might also be derived from the given name Bogumit.
} 
oremus in Polish, meaning 'objurgation, a rebuke, a reprimand, scolding'. The surname Pronobis '[pray] for us' 907 was first attested in 1692, while its likely distorted form Promobis died out in the 1990s. Other examples are Laudamus 'let us praise' 33, Noster 112 (probably from Pater Noster 'Our Father'), Agnus 5 (perhaps from Agnus Dei 'Lamb of God'), Credo 14 ('I believe', the Apostles' Creed; this name was also used historically in the form Kredo, today extinct), Beatus 'blessed' 3, Oratur ( ${ }^{\text {rd }}$ person singular passive form of the Latin verb 'to pray') 2, Dominus 'Lord' $7 /$ Domino (dative and ablative singular form of Dominus) 653 and Sekular 384 (cf. in saecula saeculorum 'forever and ever').

Certain surnames are difficult to interpret, such as Kornobis 622 (Kornobys 12, Cornobis 4), perhaps derived from Cor Jesu miserere nobis 'the heart of Jesus, have mercy on us' (from the Litany of the Sacred Heart of Jesus), and Anobis (perhaps from the collect for purity in the Roman Mass: Aufer a nobis iniquitates nostras 'take away from us our iniquities') 9.

The surnames Orant 34 and probably also Orantek 72, Orantowska 1, Orantyk 2 relate to the Latin verb orare 'speak; pray, implore', orans, -ntis 'praying'. Finally, while there is no primary surname from the Latin memento (literally 'remember' - either of two prayers in the canon of the Mass, one for living persons and the other for dead persons), there is a secondary form Mementowski 14 .

\section{Prayers, hymns, religious services and rituals}

Several surnames come from the names of various services in church. Thus, the Polish surname Jutrznia 31 is derived from jutrznia 'lauds (the divine office taking place in the early morning)'. The names Nieszpor 20, Nieszporek 803, Nieszporowski 4, Nieszporski 54, Nieszpór 10 and Nieszpur 1 all come from nieszpory 'vespers' (from Latin Vesperae < vesper 'evening'). Rorat 719, Rorata 59, Roratowski 36 and Rorot 95 all have their origin in the service called roraty 'Rorate Mass', from the beginning of the Latin hymn Rorate coeli 'Drop down ye heavens [dew] from above' (Rymut 2001: 360). The appellative panichida/panachida (Russian Панихйдa, Belorusian Паніхїа, Ukrainian Панахида) 'memorial service for the departed in the East Orthodox Church' gave rise to the names Panachida 43, Panacheda 19 and Panachet 3. Trizna, the Eastern Slavic ritual feast, in the Eastern Orthodoxy held on the grave of the deceased directly after burial, echoes in the names Tryzna 202, Tryzno 110 and Tryznowski 38. The word kadysz/kadisz 'Kaddish (in Judaism a hymn of praise to God, especially at a funeral service)' resounds in the surnames Kadysz 58, Kadyszewski 121, Kadyszyn 2, Kadiszewski 3 and perhaps Kadziszewski 130.

Names of prayers or holy hymns motivated some names as well. Kantyka 672 stems from kantyk 'canticle' (a hymn, psalm or other song of praise taken from biblical or holy texts other than the Psalms). In the Eastern Orthodox Church kontakion or

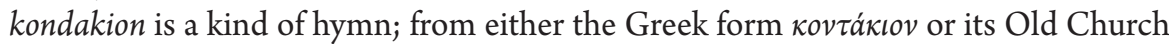
Slavonic version кондакъ stem the surnames Kondak 183, Kondaków 5, Kontak 67 and Kontakiewicz 15 (cf. Breza 2004b: 144). The word pacierz 'prayer; spine' (< Latin Pater 
Noster 'Our Father') gave Pacierz 166 and Pacierzyński 1, while its diminutive paciorek (also meaning 'prayer bead') lies at the root of Paciorak 7, Paciorek 4171, Paciorkiewicz 102, Paciorko 42, Paciorkowski 961, Paciorowski 7 and Paciorski 1. Finally, litania 'litany' can be detected in Litaniuk 8 and Litański 29.

The following surnames are related to the appellative jatmużna 'alms': Jatmużna 232, Jałmużniak 42, Jałmuźniak 2, Jałmużny 32, Jałmużýnski 14.

\section{Names of holidays}

The surname Zaduszko 27 is reminiscent of Zaduszki 'All Souls' Day', whereas Pascha 4, Paschalis 27 and Paschalski 15 can be linked with Pascha 'Easter' (Paschalis is a name first attested in Poland in the $11^{\text {th }}$ century, today having gone out of use).

Breza (2003) lists several surnames motivated by the Russian-language names of Orthodox Christian holidays. They include Btagowieszczański 6, Btagowieszczeński 9 (cf. Russian Благове́щение Пресвятой Богородищы 'Annunciation'); Kreszczyński 5 (Креще́ние Господнне 'Baptism of Jesus'); Pokrowski 66 (Покро́в Пресвятой Богоро́дищы 'the Intercession of the Theotokos', a feast of the Mother of God in the Eastern Orthodox churches, celebrated on October 1, or October 14 in the Julian calendar); Preobrażeński 8 (from Преображе́ние Господне 'the Transfiguration of Jesus'). There are several spelling variants of the name that commemorates Christmas, the birth of Christ (Рождество́ Христо́во): Rożdżestwieński 6, Rożdziestwienska 1, Rożdestwiński 5. The names Uspienska 1, Uspienskij 2, Uspieński 4, Uśpieński 15 and Uśpiński 13 all derive from Успе́ние Пресвятой Богородицы 'the Dormition of the Mother of God', corresponding to Assumption in the Catholic doctrine. Finally, Wozniesiński 2 refers to Вознесе́ние Господнне 'the Ascension of Jesus'.

As Breza (2004: 145) notes, the names Miasojed 19 and Miasojedow 9 are related to the term miasojed 'the days when it is allowed [in Eastern Orthodox Christianity] to eat meat'. Their purported cognate Miesojed 8, difficult for Breza to account for phonetically, is most probably due to the influence of Lithuanian - cf. Lithuanian mesa 'meat' and the Lithuanian surnames Mésajẽdas and Mesoédas, or even the hybrid Polish-Lithuanian Mensoé das. A related concept is miasopust (Russian Msconycm, Czech masopust), mięsopust 'carnival, or especially the last days of it, shortly before Ash Wednesday', reflected in the surnames Mięsopust 29 and Miasopust 6. Similarly, the surnames Maślenicki 4, Maślenik 24 and Maślennik 5 indicate the relationship with the above-mentioned period, in the Eastern Orthodox Church known as maslienica/ maslenica (Belorusian Масленіиа, Масьленіиа, Масьленка, Russian Масленица) - celebrated shortly before the beginning of Lent.

The surnames Spasówka 132, Spassówka 6 and Spasuwka 4 might be related to the appellative spasówka 'the fast before the holiday of Spas' (cf. Rymut 2001: 466), though indirectly: there are several villages of that name, so the surname is probably toponymic. The holiday of Spas ('Saviour'), commemorating the Transfiguration of Christ, is Eastern Orthodox, but with strong pagan roots (cf. Lozko and Wacyk 1997). 
Some more Polish surnames with the root Spas- might have similar origins (cf. Breza 2004b: 150), though alternative etymologies are also possible.

The surname Szczodrak 336 and its apparently Silesian phonetic variation Szczodrok 122 (maybe also Szczodroch 4), derived by Rymut (2001: 529) from the adjective szczodry 'generous', might have an alternative motivation. The term szczodrak, szcodraki $i^{10}$ once referred to a kind of special cake or pie in the shape of animals or dolls, given as present to children during the pre-Christian Slavic winter festival, celebrated around the time of the winter solstice, called Szczodre Gody (Ziółkowska 1989: 207).

Surnames motivated by Christian holidays do not exist in Polish alone. For instance, the Italian surname Santoro is derived from the Latin phrase festum Omnium Sanctorum 'feast of all the saints', whereas the French surnames Noël and Pascal (Latin Paschasius, Spanish Pascual, Catalan Pasqual) evoke Christmas and Easter respectively. In Croatia the surname Božić with the meaning 'Christmas' or 'young/small god' (cf. Kropej 2012: 77) ranked $16^{\text {th }}$ in popularity in 2008, with 8258 bearers ${ }^{11}$. The same name is also popular in Slovenia.

\section{Names of objects associated with the church}

Several surnames may metonymically be traceable to church objects (a tool signifies the person who uses it to do the job). In Polish onomastics such names are sometimes called indirectly occupational: derived not directly from names of occupations but from the names of objects associated with them (e.g. needle for tailor). Among them there are church vestments and accessories worn by the clergy: rokieta ('rochet' - in Polish from Italian rocchetto, utimately from Latin rochettum) - Rokieta 33; alba ('alb' - from Latin albus 'white') - Alba 55 (cf. Rudnicka-Fira 2003: 273); komża 'surplice' Komża 11, Komza 270; habit 'habit' - Habit 38, Habiciak 56, perhaps also Habiczak 6; ornat 'chasuble' - Ornat 843, Ornacki 153, Ornatowicz 6, Ornatowski 404, Ornatoski 6, Ornatkiewicz 11, Ornatek 90; tiara '(papal) tiara' - Tiara 12; infuta 'mitre' - Infulecki 87 (cf. Breza 2011: 35); stuta 'stole' - Stuła 294.

There are also names motivated by various objects used in a church. These include Gromnica 27, Gromnicki 307 - from gromnica 'thunder candle'12, cf. grom 'thunder'; Kropidto 136, Kropidtowski 2660 - from kropidto 'aspergillum'; Kropielnicki 522, Kropelnicki 71 - from kropielnica 'holy water font, stoup'; Optatek 106, Opłatkowski 124 - from optatek 'Christmas wafer'. Ikoniak 106, Ikonowicz 5 and, according to Rymut

10 The tradition of baking szczodraki in folk culture in some parts of Poland remained to this day, cf. http://www.polskieradio.pl/8/478/Artykul/293052,Lubelskie-szczodraki, accessed 02.05.2017.

11 http://www.croatian-genealogy.com/most-frequent-croatian-surnames/, accessed 17.04.2017.

12 A large beeswax candle, blessed in Poland during Candlemas (February 2), traditionally believed to ward off lightning during thunderstorms, used also in Christian rites of passage (baptism, First Communion, deathbed rituals). 
(1999: 319), also Ikan 1, Ikaniewicz 13 and Ikanowicz 10 derive from ikona, ikon 'icon'. The appellative kadzidto 'incense' lies at the root of the surnames Kadzidto 38 and Kadzidtowski 74 , though the latter name is toponymic and only indirectly connected with religion ${ }^{13}$.

Of Eastern Orthodox provenance is probably the surname Proskura 317 and its derivatives: Proskurka 2, Proskurnicki 77, Proskurniczy 2, Proskurowski 17, Proskuryn 7. As Breza (2004b: 147) maintains, at their roots lies the word proskura (or prosfora,

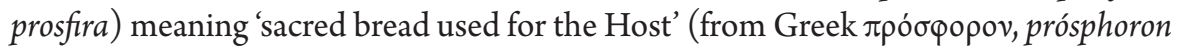
'offering', cf. also Arct 1902: 407).

\section{Places of worship}

There is a plethora of surnames motivated by the appellative kościót some are discussed in the article in the present volume devoted to the people of the church (notably Kościelny from kościelny 'sexton, sacristan. But it must be remembered that such a name may have also once referred to somebody living near a church (to that category belong also Zakościelny 508 '(living) behind a church'), Podkościelny 406 '(living) by a church'), Kościótek 1921 'little church', Kościótkiewicz 5, Kościótko 69 and Kościótkowski 10. They are semantically transparent to a layman, which cannot be said in equal measure of Czertok 8 (from czertok 'temple', cf. Breza 2004b: 142).

\section{References}

Arct - Krasnowolski, A. and W. Niedźwiedzki. Abt. 1920. M. Arcta stownik staropolski [M. Arct's Old Polish dictionary]. Warszawa: Wydawnictwo M. Arcta.

Breza, E. 2000. Nazwiska Pomorzan: pochodzenie i zmiany [Names of Pomeranians: their origin and changes]. Gdańsk: Wydawnictwo Uniwersytetu Gdańskiego.

Breza, E. 2002. Nazwiska Pomorzan: pochodzenie i zmiany II. Gdańsk: Wydawnictwo Uniwersytetu Gdańskiego.

Breza, E. 2003. Nazwiska polskie od hagionimów cerkiewnych [Polish surnames derived from Orthodox Church hagionyms]. In Chrześsijańskie dziedzictwo duchowe narodów stowiańskich, 613-619. Białystok: Wydawnictwo Uniwersytetu w Białymstoku.

Breza, E. 2004a. Nazwiska Pomorzan: pochodzenie i zmiany III. Gdańsk: Wydawnictwo Uniwersytetu Gdańskiego.

Breza, E. 2004b. Nazwiska od apelatywów cerkiewnych [Surnames derived from Orthodox Church appellatives]. In Pogranicza: kontakty kulturowe, literackie, językowe, 139-154. Białystok: Wydawnictwo Uniwersytetu w Białymstoku.

Breza, E. 2011. Nazwiska obywateli polskich, wywodzące się od wyrazów nazywających duchownych [Surnames of Polish citizens derived from words naming the clergy]. Jezyk szkota - religia 6: 32-48.

13 Kadzidło, a village in Ostrołęka County in east-central Poland, is known for its exploitation of amber, whose tiny pieces used to be placed by the Kurpie people in bonfires to give them an incense-like smell (this custom earned them the nickname kadzidlaki 'the incense people', although the incense they made was of secular rather than church use). 
Brückner, A. 1927. Słownik etymologiczny języka polskiego [Etymological dictionary of Polish]. Kraków: Krakowska Spółka Wydawnicza.

Kościński, K. 1906. Parafija kaszubska Konarzyny: obrazek historyczny [Kashubian parish of Konarzyny]. Roczniki Towarzystwa Naukowego w Toruniu 13: 6-160.

Kropej, M. 2012. Supernatural Beings from Slovenian Myth and Folktales. Ljubljana: Založba ZRC.

Kryciński, S. 2016. Łemkowszczyzna po obu stronach Karpat [Lemkivshchyna on both sides of the Carpathian Mountains]. Rzeszów: Libra PL.

Lozko, G. and A. Wacyk. 1997. Rodzima wiara ukraińska [Ukrainian Native Faith]. Wrocław: Toporzeł.

Poniatowski, Z. (ed.). 1969. Mały stownik religioznawczy [Concise dictionary of religious studies]. Warszawa: Wiedza Powszechna.

Rudnicka-Fira, E. 2003. Elementy łacińskie w nazwach osobowych (nazwiskach) mieszkańców Krakowa od XVI do XVIII w. [Latin elements in the personal names (surnames) of the inhabitants of Cracow in the $16^{\text {th }}-18^{\text {th }}$ centuries] In Śląskie studia lingwistyczne, 272-279. Katowice: Wydawnictwo Uniwersytetu Śląskiego.

Rymut, K. 1999. Nazwiska Polaków: Stownik historyczno-etymologiczny I [Surnames of Poles: historical-etymological dictionary]. Kraków: IJP PAN.

Rymut, K. 2001. Nazwiska Polaków: Stownik historyczno-etymologiczny II. Kraków: DWN.

Rymut, K. 2005. Stownik nazwisk używanych $w$ Polsce na początku XXI wieku. Wydanie drugie poprawione [Dictionary of surnames used in Poland at the turn of the $21^{\text {st }}$ century, second edition, revised]. Kraków: IJP PAN. CD-ROM.

SGKP - Stownik geograficzny Królestwa Polskiego i innych krajów stowiańskich [Geographical dictionary of the Kingdom of Poland and other Slavic countries]. 1880-1914. Warszawa: nakł. Filipa Sulimierskiego i Władysława Walewskiego.

SJPDor - Doroszewski, W. (ed.). Słownik języka polskiego [Dictionary of Polish]. 1958-1969. Warszawa: Wydawnictwo "Wiedza Powszechna"/PWN.

SWil - Stownik języka polskiego [Dictionary of Polish], compiled by A. Zdanowicz et al. 1861. Wilno: M. Orgelbrand.

Szczaus, A. 2003. Wyrazy złożone z komponentem bog w historii polszczyzny [Compounds with the element bog in the history of Polish]. In Chrześcijańskie dziedzictwo duchowe narodów stowiańskich, 413-424. Białystok: Wydawnictwo Uniwersytetu w Białymstoku.

Van Langendonck, W. 2012. Diachronic Classification of Bynames Given by Adults, and Bynames Given by Young People. In Name and Naming: Synchronic and DiachronicPerspectives, O. Felecan (ed.), 222-233. Newcastle upon Tyne: Cambridge Scholars Publishing.

Ziółkowska, M. 1989. Szczodry Wieczór, Szczodry Dzień - obrzędy, zwyczaje, zabawy [The Slavic Koliada - rituals, customs and games]. Warszawa: LSZ. 